\title{
Statistical Survey of Students' Performance: Online Education to COVID-19 in Bangladesh
}

\author{
Tanjea Ane ${ }^{1}$, Tabatshum Nepa ${ }^{2}$ \\ ${ }^{1}$ Bangabandhu Sheikh Mujibur Rahman Agricultural University, Gazipur, Bangladesh \\ ${ }^{2}$ Gono Bishwabidyalay, Dhaka, Bangladesh \\ Email: tanjea@bsmrau.edu.bd,niipa.ju35@gmail.com
}

How to cite this paper: Ane, T. and Nepa, T. (2021) Statistical Survey of Students' Performance: Online Education to COVID19 in Bangladesh. Open Access Library Journal, 8: e8054.

https://doi.org/10.4236/oalib.1108054

Received: October 7, 2021

Accepted: November 27, 2021

Published: November 30, 2021

Copyright (C) 2021 by author(s) and Open Access Library Inc.

This work is licensed under the Creative Commons Attribution International License (CC BY 4.0).

http://creativecommons.org/licenses/by/4.0/

(c) (i) Open Access

\begin{abstract}
Pandemic situation stops natural movement in the globe but still not curb the spread of education. Formal education could be transformed into online education in smart version of teaching learning system especially for university students in Bangladesh. Such in shutdown and worse pandemic tenure schooling are brought into students' residence in the dynamic form just like students globalization. How the university students are performing with online learning and technology is being adopted in classroom have outlined in our study. To evaluate new achievement in online education: online survey is designed to collect feedback from Bangladesh and Nepal undergraduate university students in Bangladesh at COVID-19 lockdown period. Survey data is compiled using google forms part of google drive apps and students corresponding email accounts, both student and teacher performance was recorded in BdREN vSession. Responses are discussed demographically in result discussion section. This article indicates offline classroom is not only an option for teaching learning system, technology based education is entering as advanced and alternative way however its' in worst pandemic or challenging situation, and then characterize future education image for students.
\end{abstract}

\section{Subject Areas}

E-Learning and Knowledge Management, Higher Education

\section{Keywords}

Online Learning, BdREN vSession, COVID-19, Higher Education

\section{Introduction}

Modern technology added few new smart features in education and it seemed 
noticeable that the mobile phone and fast internet use could have a significant impact on teaching and learning environment. Mobile phones as educational tools have been popularity through the entire society around the world with other technical devices. Thus technology connects whole education system for distance data acquiring and knowledge sharing thus results in enhancing leaning opportunities to learning seekers [1].

IoT technology in education was introduced to smart classroom in order to make good and efficient lectures' presentation as well listeners' active attention. Also helps consistently interesting presentation which enormously benefitted for students and makes learning way easier, approximately short and even more interactive than formal education procedure [2]. This study [3] reviewed 47 published research works then stated on online teaching-learning environment and clearly suggested an effective planning for development online course designing. Mobile learning (m-learning) indicates learning through small/portable computing devices, the researcher believes that [4] mobile learning bridges a communication between teachers and learners through its services that effects in distance learning. Technologies and smart mobile phone together makes diversity in teaching learning area [5]. Now accessing course content even sharing lectures from different universities in Bangladesh has been possible through online learning. Paper [6] had an overview both IoT advantages and disadvantages in education systems for Curtin university students. Authors' another paper [7] showed that virtual objects connected in smart classroom makes a dynamic improvement than traditional education system. Advanced education spreads the knowledge diversity with integrating new technology in higher level education which has highlighted smart classroom in real time [8]. COVID-19 challenges are focused and possible solutions are briefly described with statistical analysis in [9] using existing technology.

Due to pandemic situation, formal education transformed into online education with virtual classes and addressed the essentialities requirement for online education management [10]. IoT technology changes classroom approaches in effective way that makes it easier to cut down challenging of teacher, student practice issues and save both a lot of time. Effects of Information system in French University students education system was experimented and shown in [11]. To remove education gap comparing others country study, [12] shows the students attention in e-education at teachers view. Online education is innovative and enthusiastic teaching-learning mode for post-graduation students [13]. Therefore above studies significantly indicate a high time to welcome dynamic and efficient change in education management especially through a convenient online platform for all participants at any pandemic period and at any distance. Author in [14] statistically analyzed data from Dhaka and Chaittagong cities in Bangladesh education performance that results online education creates unfavorable pressure for both teaching and learning due to financial problems.

This article explores online teaching learning mode for university students' 
and their responses have been discussed then analyzed from online survey data to high up learning output. Participants' number, online backgrounds, materials, survey questionnaires design described in participants' response section. Tables and figures are statistically measured with appropriate parameters under students' response with online learning method and then discussed in result discussion section, and technological impact of Bangladesh academic site is estimated in future education section.

\section{Study Objectives}

Covid-19 had a severe possibility hampering basic needs of human around the world and impact on educational sector in global. An alternative outcome was demanding at beginning to curb the bad impact of COVID-19 curse on students' higher education. Researchers proposed an efficient and friendly network for learning environment for students that is online education. In our study, we tried to realize actual online study requirements, students' interaction with online platform, expectation for future learning and explored the students' opinions through online survey from both Bangladesh and Nepal students. As online education was not practiced well before pandemic, teacher and students response with new online platform like unfamiliar environment naturally, new online education platform appeared as concerning technical media. It was accepted cordially and equally challenging.

\section{Participants Response}

\subsection{Survey Questionnaire Design}

To analysis students response online survey-questionnaire was provided among 250 students perusing under graduation level in university from both Bangladesh and Nepal. Among of them quite 208 students submitted responses. An online questionnaire template was designed that contains relevant information about online classes, lab, teaching-learning interaction, course content, internet availability. Each student got access questionnaire link using "Google form" and participated survey just signing on their mail account. Students reflected their views by selecting right opinion from given different options on google form.

Students took class session in Bangladesh Research and Education Network (BdREN) for high throughput with constant connection, class videos were uploaded as youtube tutorial for better learning in later if needed and WhatsApp group was created for group discussion. Lab experiments were performed sharing devices' screen at class period. Class content presentation files are sent to individual student as mail attachment. At exam date, examiner tracked candidates' attendance record in BdRen network vSession, all examinee were on-video state during exam session and theory exam was recorded by instructor for evaluation.

\subsection{Survey Questionnaire Pattern}

A Google form is easy to design and be presentable in concise format. Three 
crucial parts such as questions, responses and settings. Appropriate data selected to be asked, are set on question part. Results are automatically generated as summary in responses part. Settings kept as default. A survey template contains a range of question with options: multiple choices, checkboxes, dropdown, short answer and paragraph. For questionnaire four sections are chosen. Firstly, added title and students' profile in one section, options are chosen as multiple choose, cues has no space for typing text. Secondly, section is designed with checkbox and adding a range of questions only for students' preference tools for online class. Thirdly, dropdown options are set another section to collect students' satisfactory level. Lastly for opinion and suggestions from students as short answer questions are linked in section. To complete input as answer/response there is submit button at bottom of google form.

\section{Result Discussion}

Undergraduate 208 students completed the survey questionnaire. A questionnaire contains relevant information about online classes, lab, teaching-learning interaction, course content, and internet availability written over google forms and get answered to collect data from local and foreign students. Each student get access questionnaire link using "Google form" and participated on survey just signing on their mail account.

\subsection{Result Discussion-Students Profile}

Table 1 shows students profile indicating their gender, country, term criteria. Public university students in Bangladesh significantly contributed for data surveillance. Figure 1(a) and Figure 1(b) show a graphical representation of students participation from Bangladesh and Nepal enrolled three terms in a year.

\subsection{Result Discussion-Students Response with Smartphone}

Online teaching-learning has been made handy with fast data network web access and smart features such as camera, microphone, bluetooth, apps installing, s-capture, personal hotspot, split screen all together enables mobile phones to represent online course smartly, efficiently and interactively. Figure 2(a) and

Table 1. Students profile.

\begin{tabular}{cccc}
\hline Students Profile & & Frequency & Percentage (\%) \\
\hline \multirow{2}{*}{ Gender } & Male & 101 & $45 \%$ \\
& Female & 107 & $55 \%$ \\
\hline \multirow{2}{*}{ Living Country } & Bangladesh & 148 & $82.2 \%$ \\
& Nepal & 60 & $17.8 \%$ \\
\hline \multirow{2}{*}{ Enrolled Term/Semester } & Summer-2020 & 21 & $5.6 \%$ \\
& Autumn-2020 & 112 & $83.2 \%$ \\
& Winter-2020 & 75 & $11.2 \%$ \\
\hline
\end{tabular}




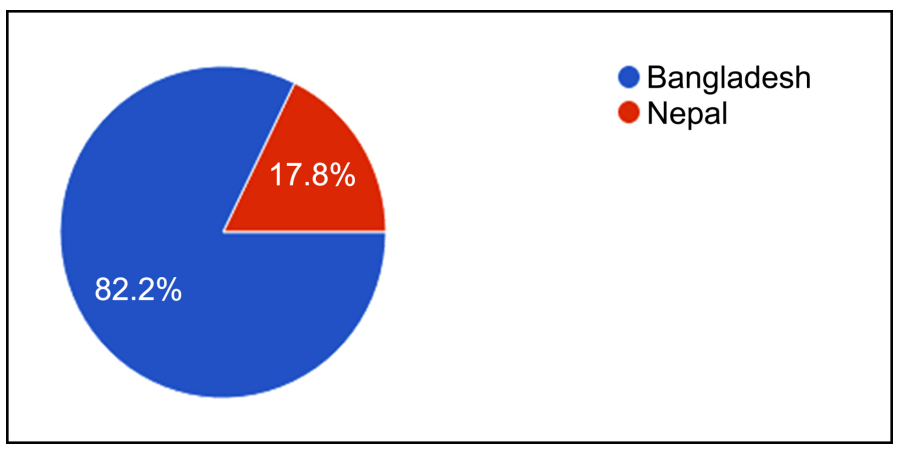

(a)

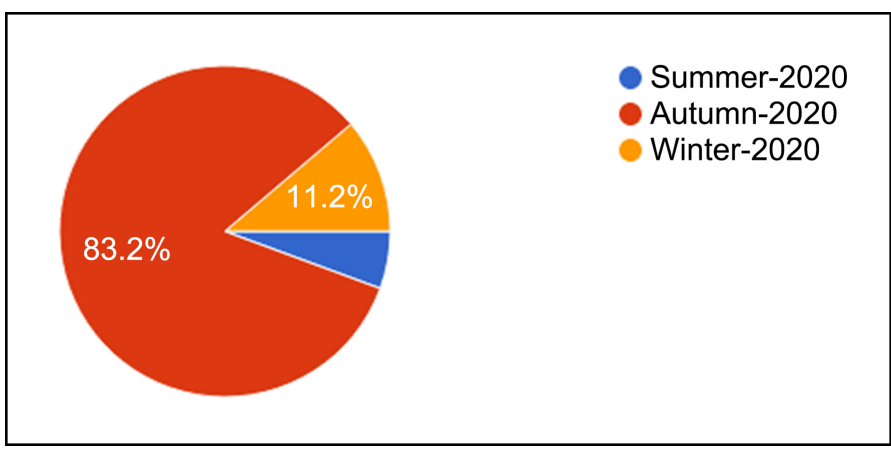

(b)

Figure 1. Students residence area during Lockdown and enrolled term in year 2020. (a) Local and foreign students data ratio; (b) Participation in term.

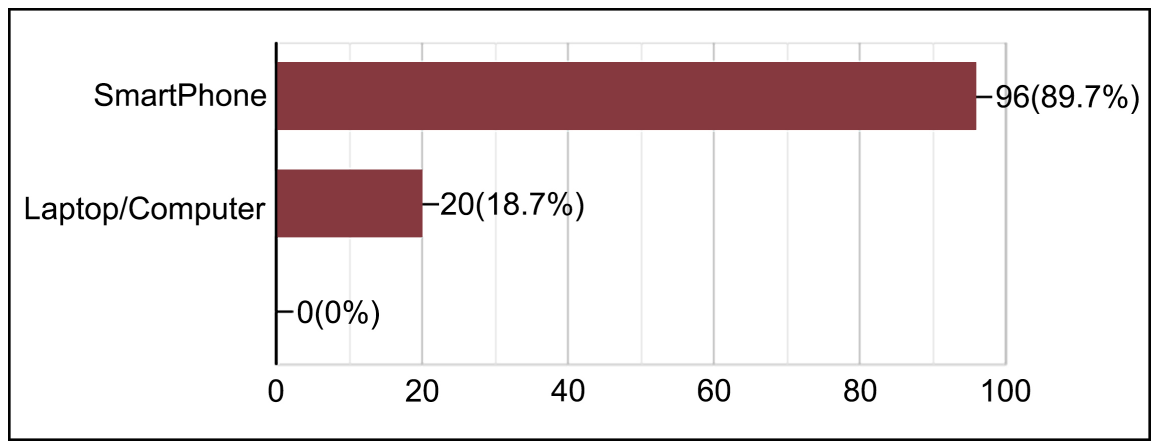

(a)

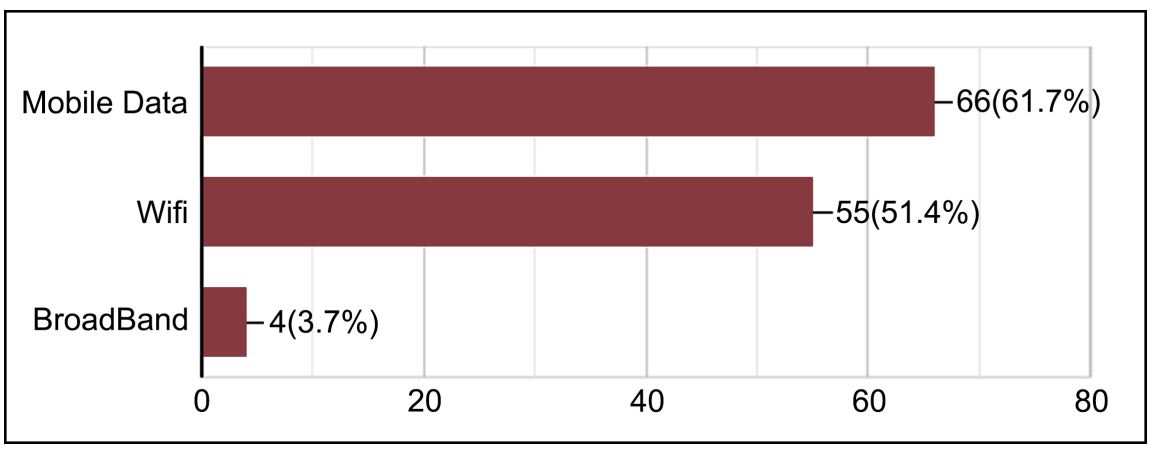

(b)

Figure 2. Students prefer Smartphone for online classes. (a) Response with Smartphone preference; (b) Mobile Data network is fast responding. 
Figure 2(b) show students enjoy online classes on their mobile phone and smartphone gets popularity for online classes. Smartphone and laptop/computer are both accessed by students but smartphone gets highly accessed (89.7\%) at a time mobile data (61.7\%) and Wi-Fi (51.4\%) are used for data accessing, broadband in less used for online classes only 3.7\%. Students using smartphone sometimes likely take class with their laptop/computer (18.7\%). Since mobile data package is offered with discount and seems cheap than Wi-Fi connection so students mostly access online study materials using mobile internet.

\subsection{Result Discussion-Students Satisfaction}

Survey data in Figure 3(a) and Figure 3(b) revealed students strongly agree that class lecture videos are supportive $(47.2 \%)$ and (13.1\%) highly appreciate online exam evaluation but (63.6\%) accepted online evaluation policy with different opinions. Another Figure 4(a) and Figure 4(b) has shown students think sometimes technological and essential supports are not available with online education $(95.3 \%)$ and minor cases feel it has well designed online support while they are dissatisfied (44.3\%) with lab inefficiency and they put effective suggestions for improving lab facilities during lockdown classes.

There were also indications that some students were not able to use lab accessories. So, they were too late to complete lab task and sometime wait others student to get assignment done and then can access their computers or laptops.

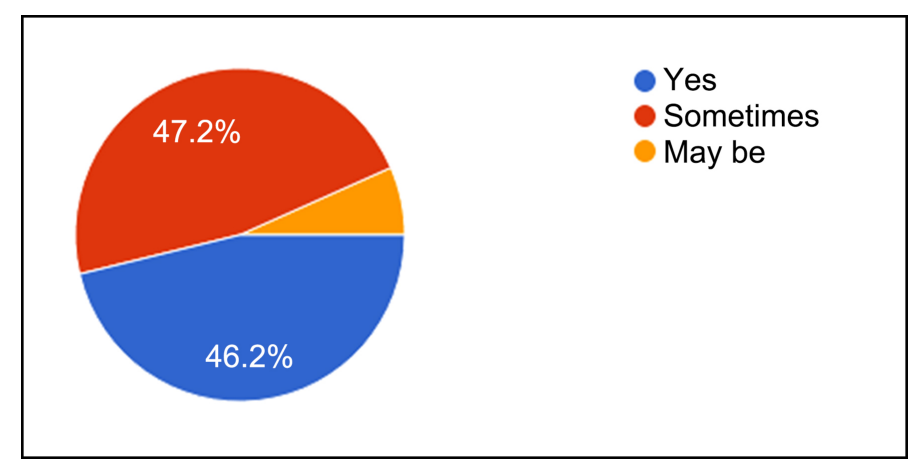

(a)

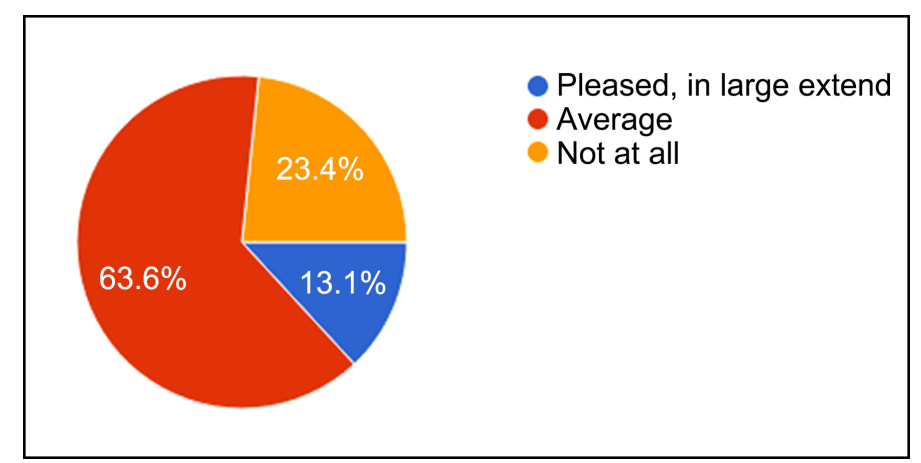

(b)

Figure 3. Students response with class videos and exam evaluation. (a) Supportive class videos; (b) Online examination satisfaction. 


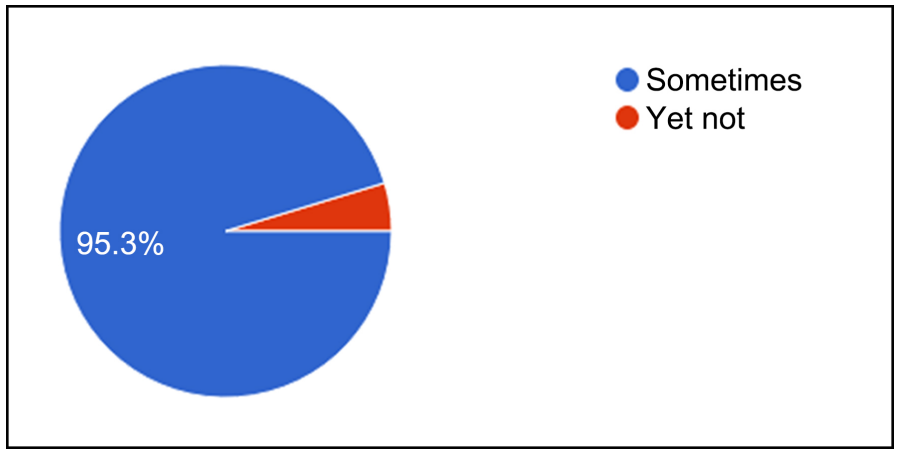

(a)

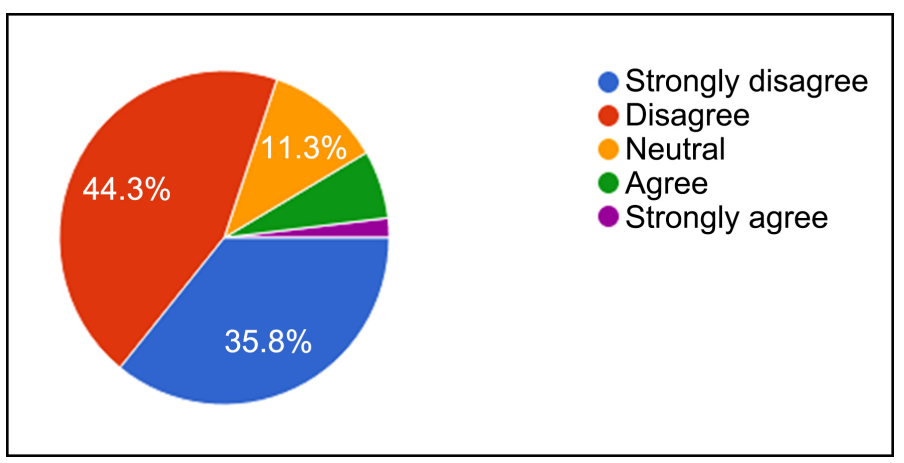

(b)

Figure 4. Students opinion and suggestion for online education management. (a) Major difficulties facing; (b) Lab access and efficiency on time.

\section{Imaging Future Education in Bangladesh}

In response to significant demand at period of Covid-19 we all teachers and students globally accept online digital education as alternative but effective tools. In Post Covid-19 like university going situation, there is highly possibilities to continue e-learning education. Students' response and their viewpoint for future have shown in Table 2. Students positively interacted with interactive online education. It has definitely huge good signs for Bangladesh students that cut down dropout number and at a time influence them to be more attentive with new online education system. As before students not concisely waste a lot time accessing web series/videos at different link which are not good searching for them. That was partially replaced with e-books/online resource searching due to result of online learning. Bangladesh has started following online education practicing in unplanned way with little preparation, no training and limited resources. Before COVID-19 pandemic, a study survey got positive result in [15] that analyzed, all academic staffs highly responded to new emerging e-learning policy rather than being used to study only using traditional education techniques. Figure 5 shows comparative and graphical view of e-learning responses for students and teachers category. Among teachers 80 percentage of them prefer e-learning and 60 percent students agree to e-learning as acceptance technique for education system in Bangladesh. From comparative discussion it is clearly declared, pandemic situation starts online education for students and 
Table 2. Students thoughts about online learning.

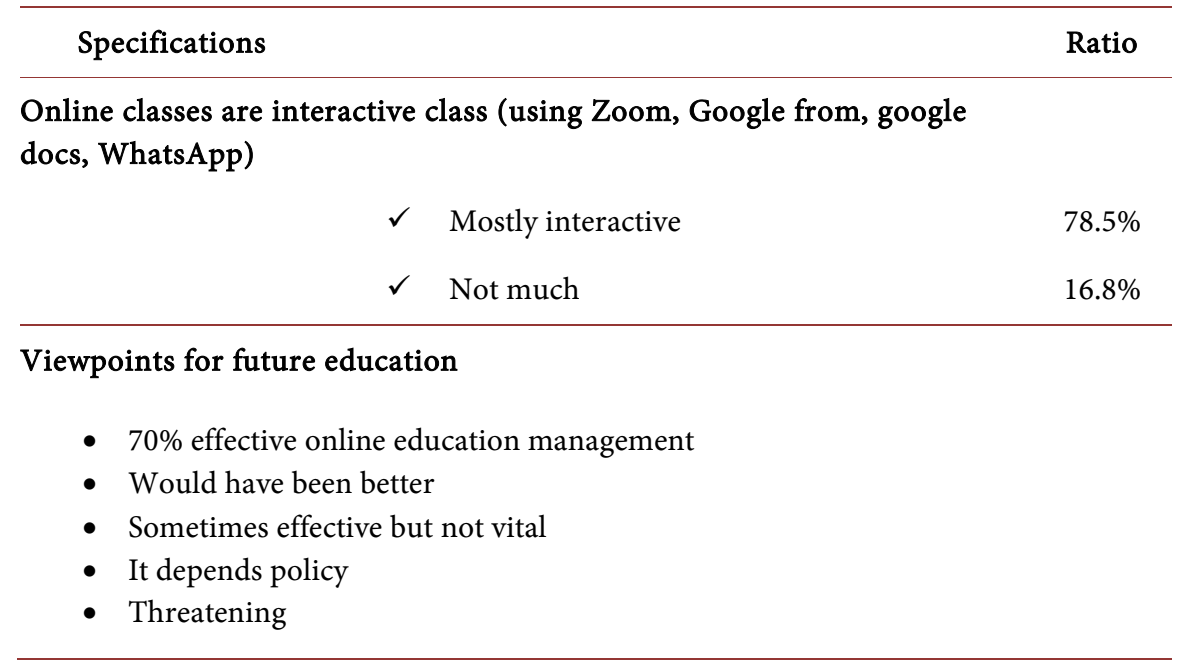

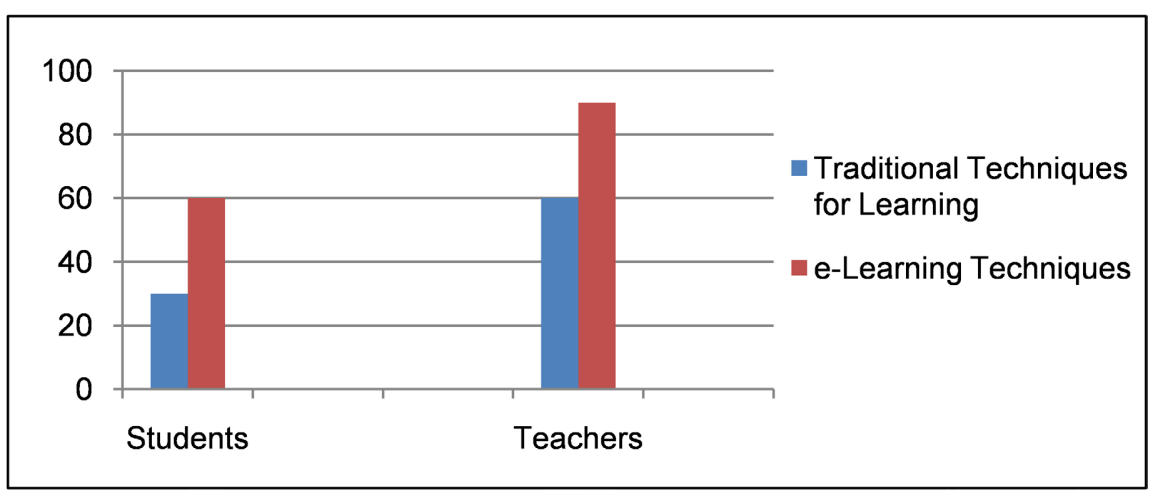

Figure 5. Comparative view of old and new e-learning system (in \%).

teachers formally but better effects of online teaching and learning will continue after pandemic. Online education added new challenges with education sector for students and forward them to compete with other students globally. This study suggest, we shall not stop online education rather online education concepts would be integrated with existing education system to accelerate our education sector in future.

\section{Conclusion}

During pandemic worse situation, it has been reached crucial phase which a decisive outcome is impending for uninterrupted teaching in University of Bangladesh. We all teachers and students compelled to attend in class, meeting, workshop even for examination through virtually. Therefore, here is really nothing else to think backward where online educational program in university goes quite smoothly around the clock amid pandemic situation. On the flip side, countryside students are able to participate equally though coming across new few technological constraints. Furthermore, not to being idle, more practical, time convenient and vital decisions have been taken by academic council for 
university students that is the way of teaching and learning virtually in more interactive medium to keep focus students attention in learning. This article comparatively shows that online platform for education should be established and maintained for higher education. Its' not give up formal offline education system rather need to accept both to improve quality and researchers feel positive change undoubtedly necessary in order to dynamically maximize output in education policy.

\section{Conflicts of Interest}

The authors declare no conflicts of interest.

\section{References}

[1] Körösi, G. and Esztelecki, P. (2015) Implementation of Mobile Phones in Education. Research in Pedagogy, 5, 94-104. https://doi.org/10.17810/2015.08

[2] Temkar, R., Gupte, M. and Kalgaonkar, S. (2016) Internet of Things for Smart Classrooms: International Research Journal of Engineering and Technology (IRJET), 3, 204-207. https://www.irjet.net/archives/V3/i7/IRJET-V3I739.pdf

[3] Sun, A. and Chen, X. (2016) Online Education and Its Effective Practice: A Research Review. Journal of Information Technology Education: Research, 15, 157-190. http://www.informingscience.org/Publications/3502 https://doi.org/10.28945/3502

[4] Nail, B. and Ammar, W.A. (2017) Mobile Learning Education Has Become More Accessible. American Journal of Computer Science and Information Technology, 5, Article No. 5. https://doi.org/10.21767/2349-3917.100005

[5] Sultan, M.N., Ali, E., Ali, M.A., Nadim, M. and Habib, A.M. (2017) Smart Campus Using IoT with Bangladesh Perspective: A Possibility and Limitation. International Journal for Research in Applied Science \& Engineering Technology (IJRASET), 5, 1681-1690. https://doi.org/10.22214/ijraset.2017.8239

[6] Kent, M., Ellis, K. and McRae, L. (2018) Internet of Things (IoT): Education and Technology. The Relationship between Education and Technology for Students with Disabilities. Curtin University of Technology, School of Media, Creative Arts and Social Inquiry (MCASI). http://hdl.handle.net/20.500.11937/69810

[7] Ane, T., Billah, M. and Nepa, T. (2020) Performance of Internet of Things (IoT) Potential Applications in Education. Bangladesh Journal of Multidisciplinary Scientific Research, 2, 10-16. https://doi.org/10.46281/bjmsr.v2i2.653

[8] Premalatha, B. and Krishnan, J.H. (2020) IoT Based Smart Classroom. International Journal of Scientific \& Technology Research, 9, 1644-1650.

[9] Emon, E.K.H., Alif, R.A. and Islam, M.S. (2020) Impact of COVID-19 on the Institutional Education System and Its Associated Students in Bangladesh. Asian Journal of Education and Social Studies, 11, 36-46. https://doi.org/10.9734/ajess/2020/v11i230288

[10] Mishra, L., Gupta, T. and Shree, A. (2020) Online Teaching-Learning in Higher Education during Lockdown Period of Covid-19 Pandemic. International Journal of Research Open, 1, Article ID: 100012. https://doi.org/10.1016/j.ijedro.2020.100012

[11] Sukare, N. and Sharma, M. (2021) Smart Classroom Environment Using IoT in Advanced and Lebanese French University Education. Turkish Journal of Computer and Mathematics Education, 12, 2185-2191. 
[12] Tabassum, M., Mannan, S.E., Parvej, M.I. and Ahmed, F. (2021) Online Education during COVID-19 in Bangladesh: University Teachers' Perspective. AQUADEMIA, 5, Article ID: ep21005. https://www.aquademia-journal.com/ https://doi.org/10.21601/aquademia/9611

[13] Li, Y., Wen, X., Li, L., Zhou, E., Y., Huang, L., Ling B., Liao, X. and Tang, Q. (2021) Exploration of Online Education Mode for Postgraduate Education under the Background of COVID-19. Advances in Applied Sociology, 11, 223-230.

https://doi.org/10.4236/aasoci.2021.115019

[14] Rahman, M.M. (2021) Statistical Analysis of Bangladesh Education System before and after COVID 19. International Journal of Economics, Business and Management Studies, 8, 31-40. https://doi.org/10.36713/epra8064

[15] Gaur, S., Chaudhary, A. and Mittal, M. (2015) A Comparative Study of E-Learning Technique with Traditional Teaching Techniques. International Journal of Innovative Research in Electrical, Electronics, 3, 23-25.

https://doi.org/10.17148/IJIREEICE.2015.3806 